\title{
The influence of dental loupes on the quality of adhesive removal in orthodontic debonding
}

\section{Einfluss von Lupenbrillen auf die Qualität der Adhäsiv- Restentfernung bei orthodontischem Debonding}

\author{
Denis F. Baumann ${ }^{1 *}$, Lorenz Brauchli ${ }^{1 *}$, Hubertus van Waes ${ }^{2}$
}

\begin{abstract}
Objective. Bracket bonding has been a major advance in orthodontic treatment. However, the method of debonding can lead to diverse problems such as enamel fractures, enamel loss and enamel scratching. In this clinical investigation we aimed to evaluate the influence of wearing dental loupes on enamel damage during the debonding procedure.

Material and Methods. 22 consecutive patients were randomly assigned in a split-mouth study to evaluate adhesive removal with and without the use of dental loupes (2.5×, LED headlight). Tooth replicas in epoxy resin were made from silicone impressions. Electron microscopic images (50x magnification) of 394 buccal enamel surfaces were evaluated according to an enamel damage index (EDI), line angle grooves (LAG) and composite residues (CR) on anterior teeth, premolars and molars.

Results. The EDI revealed highly significant advantages for debonding with dental loupes, with which the EDI was significantly higher for molars, while still less than without dental loupes. We detected no differences between the tooth groups without dental loupes. We found significantly fewer LAG on anterior teeth debonded with dental loupes. CR were fewer in the dental loupes group, and we noted no significant differences between the tooth groups.

Conclusions. Dental loupes affect the quality of the debonding procedure, resulting in less enamel damage and composite residue, as well as fewer LAG compared to the control group. We therefore strongly recommend the use of dental loupes in orthodontic debonding procedures.
\end{abstract}

\section{Keywords}

Debonding · Enamel · Surface · Roughness · Loupe · Magnification

${ }^{*}$ D.F. Baumann and L. Brauchli contributed equally to this research.

${ }^{1}$ Clinic of Orthodontics and Pedodontics, Dental School, University of Basel, Switzerland

${ }^{2}$ Pediatric Dentistry Program, University of Zurich, Switzerland

Received: November 15, 2010 ; accepted: December 29, 2010

\section{Zusammenfassung}

Hintergrund und Ziel. Adhäsivtechniken im Bracketbonding brachten einen großen Fortschritt in der kieferorthopädischen Therapie. Die Techniken zur Adhäsiv-Restentfernung nach Debonding können allerdings zu verschiedenen Problemen führen, wie Schmelzfrakturen, Schmelzverlust und Riefenbildung. Ziel dieser klinischen Untersuchung war die Evaluation des Einflusses der Benutzung von dentalen Lupenbrillen auf Schäden am Schmelz während der Adhäsiv-Restentfernung.

Material und Methodik. In einem randomisierten Split-MouthVersuch wurden 22 konsekutive Patienten bezüglich Adhäsiv-Restentfernung mit oder ohne dentaler Lupenbrille (2,5x, LED-Stirnlicht) untersucht. Nach erfolgter Adhäsiv-Restentfernung wurden über Silikonabformungen Zahnreplika auf Epoxidharzbasis hergestellt. Elektronenmikroskopische Aufnahmen von 394 Bukkalflächen wurden bei 50-facher Vergrößerung nach folgenden Kriterien beurteilt: Schmelzschadenindex (EDI), "Line-Angle"-Rillen (LAG) und Kompositreste (CR). Dies wurde für die Frontzähne, Prämolaren und Molaren getrennt durchgeführt.

Ergebnisse. Der EDI zeigte einen hochsignifikanten Vorteil für das Debonding mit Lupenbrille. Mit Lupenbrille war der EDI an Molaren zwar signifikant höher als in den vorderen Zahnregionen, jedoch immer noch tiefer als ohne Lupenbrille. Ohne Lupenbrille konnten keine Unterschiede zwischen den verschiedenen Zahngruppen festgestellt werden. Bei Debonding mit Lupenbrille traten zudem signifikant weniger "Line-Angle“-Rillen an Frontzähnen auf. Kompositreste fanden sich unter Verwendung einer Lupenbrille seltener, und es bestanden keine signifikanten Unterschiede zwischen den Zahngruppen.

Schlussfolgerungen. Die Verwendung dentaler Lupenbrillen beeinflusst die Qualität der Adhäsiv-Restentfernung und hinterlässt weniger Schmelzschäden, „Line-Angle“-Rillen und Kompositreste. Die Verwendung von dentalen Lupenbrillen kann für die Adhäsiv-Restentfernung klar empfohlen werden.

\section{Schlüsselwörter}

Debonding · Schmelz · Oberfläche · Rauheit · Lupe · Vergrößerung

J Orofac Orthop 2011; 72:125-132

DOI 10.1007/s00056-011-0010-y 


\section{Introduction}

Dental loupes are widely used in dentistry. Advantages in work ergonomics $[4,8,9,10,18,20]$ and precision $[8,17]$ have been reported. Dental loupes are even mandatory in endodontic specialty training in the US [10]; students should master their use as early as possible within the curriculum [18]. Dental loupes also offer eye protection. The majority of ocular traumata suffered by orthodontists occur while debonding and trimming acrylic [27].

However, studies on the efficiency of dental loupes in orthodontics treatment have not been reported in the literature. Whereas many aspects of orthodontic treatment rely on a good view of one or both dental arches at a time, some, such as bracket placement or adhesive removal after debonding, might profit from enhanced visual control by magnifying loupes.

The bonding of brackets was undoubtedly a major contributor to advances in orthodontic technology in the last century. However, new challenges arose in bracket removal and adhesive clean-up. Various adhesive-removal techniques have been investigated to assess the amount of enamel loss [1, 2, 13, 31], and values between 7 $\mu \mathrm{m}$ and $170 \mu \mathrm{m}$ reported, with most values ranging between $20 \mu \mathrm{m}$ and $50 \mu \mathrm{m}$. Compared to enamel thicknesses of 1500-2000 $\mu \mathrm{m}$ [30], this loss does not seem problematic. However, the outer enamel layer is harder and more densely mineralized [22]. This surface layer has a thickness of approximately $20 \mu \mathrm{m}$ [22] and is removed or reduced during adhesive removal. It therefore seems prudent to reinforce the enamel by applying fluoride after debonding.

In addition to enamel loss, composite residues and surface damage represent two further potential problems. Several studies have reported composite residues [12, 23,33], and it seems difficult to ensure removal of all composite in a daily clinical environment [3, 5]. Surface damage has been considered in combination with various adhesive removal protocols using burs, discs, cups, slurry of different materials and sequences, as well as air-powder abrasive devices [11], lasers [29], ultrasonic techniques [16] and intraoral sandblasting [15]. Most authors agree that any remaining adhesive is best removed with a tungsten-carbide bur [7, 12, 23, 32, 33]. Discs $[24,33]$, polishing slurry $[1,33]$, rubber prophy points and fiberreinforced resin burs [24] have been successfully employed for subsequent polishing.

In contrast to an earlier investigation [19] reporting that enamel defects after adhesive removal were reduced by normal wear, no such changes were observed in a recent study using scanning electron microscopy (SEM) [26]. Brown and Way [2] observed less loss of enamel in clinical debonding than in vitro, since the superior vision (due to illumination and better drying) in the in-vitro set-up lead to more thorough (and probably more destructive) cleaning.

It was the aim of this study to investigate the effect of wearing dental loupes on iatrogenic damage to the enamel in the form of surface defects, line angle grooves and the presence of composite residues.

\section{Material and methods}

After obtaining approval of our study protocol from the Ethics Committee of the Public Health Administration Canton of Zurich (StV No. 07/05), 22 consecutive patients (13 females, nine males;

\section{Einleitung}

Dentale Lupenbrillen werden in der Zahnmedizin weitverbreitet eingesetzt. Vorteile bezüglich Arbeitsergonomie [4, 8, 9, 10, 18, 20] und Präzision $[8,17]$ wurden diskutiert. Dentale Lupenbrillen sind im Endodontie-Spezialisierungsprogramm in den USA obligatorisch [10], und die Studenten werden von Beginn an zur Verwendung dentaler Lupenbrillen angehalten [18]. Lupenbrillen schützen zudem die Augen. Die Mehrheit der Augenverletzungen bei Kieferorthopäden erfolgt während Debonding und Beschleifen von Kunststoffen [27].

Studien zur Effizienz der Verwendung von Lupenbrillen in der orthodontischen Behandlung liegen nicht vor. Während in der Kieferorthopädie viele Arbeiten von einer guten gleichzeitigen Übersicht über beide Zahnbögen abhängen, könnten Lupenbrillen für Arbeiten wie Bracketplatzierung oder Kunststoffentfernung nach Debonding vorteilhaft sein.

Die Bracket-Klebetechniken stellten in der kieferorthopädischen Behandlung im letzten Jahrhundert zweifelsfrei einen großen Durchbruch dar; allerdings entstanden neue Probleme bei der Entfernung der Brackets und des Restadhäsivs. Es wurden unterschiedliche Methoden zur Adhäsiv-Restentfernung untersucht, wobei für den Schmelzverlust Werte zwischen 7 und $170 \mu \mathrm{m}$ bei mittleren Werten von 20-50 $\mu \mathrm{m}$ gefunden wurden $[1,2,13,31]$. Im Vergleich zur Schmelzdicke von 1500-2000 $\mu \mathrm{m}$ [30] scheint dies unproblematisch. Allerdings weist die äußere Schmelzschicht eine bessere Mineralisierungsstruktur auf [22]. Diese oberflächliche Schicht hat eine Dicke von ca. $20 \mu \mathrm{m}$ und wird während der Adhäsiv-Restentfernung reduziert, oder eliminiert [22]. Deshalb scheint es sinnvoll, den Schmelz nach Debonding mit Fluoriden zu behandeln.

Neben dem Schmelzverlust stellen Kompositreste und Schmelzschäden zwei weitere potenzielle Problemfelder dar. Kompositreste nach Debonding wurden in verschiedenen Studien [12, 23, 33] dokumentiert. Es scheint in der täglichen klinischen Arbeit schwierig zu sein, sämtliche Kompositreste zuverlässig zu entfernen $[3,5]$. Bezüglich Schmelzschäden wurden in verschiedenen Untersuchungen unterschiedliche Adhäsiv-Restentfernungsmethoden mit Bohrern, Disks, Näpfchen, unterschiedlichen Pasten sowie Air-Abrasion [11], Laser [29], Ultraschall [16] und intraoralem Sandstrahlen [15] untersucht. Die meisten Autoren kamen überein, dass die Adhäsiv-Restentfernung am besten mit Wolfram-Karbidbohrern vorgenommen werden sollte $[7,12,23,32,33]$. Für die anschließende Politur wurden Disks [24, 33], Polierpasten [1, 33], Gummispitzen oder faserverstärkte Kunststoffbohrer [24] empfohlen.

Die Resultate einer früheren Studie [19], die zum Schluss kam, dass sich Schmelzdefekte nach Adhäsiv-Restentfernung mit der Zeit durch normale Abnutzung verringern, konnten in einer neueren REM-Untersuchung nicht bestätigt werden [26]. Braun u. Way [2] stellten zudem fest, dass bei alltäglichem Debonding in der Klinik weniger Schmelzverluste gefunden wurden als im In-vitro-Versuch, weil dort die verbesserten Sichtverhältnisse, aufgrund besserer Beleuchtung und Darstellung durch Trocknung der Zähne, eine gründlichere (aber wahrscheinlich auch destruktivere) AdhäsivRestentfernung ermöglichen.

Ziel der vorliegenden Studie war, die Auswirkung des Tragens von dentalen Lupenbrillen auf iatrogene Schäden am Schmelz in 
mean age $16.9 \pm 3.0$ years; maximum 27.6 years, minimum 14.0 years) resulting in a total of 394 teeth were included in this study. Teeth with rebonded brackets $(n=26)$ were excluded from our study cohort, as were teeth with buccal caries, demineralization or fillings. We used a split-mouth design in which one quadrant of each jaw was randomly assigned to either the loupes or control group, with the contralateral quadrant assigned vice versa. All patients were debonded by the same orthodontist (mean treatment time $2.2 \pm 0.8$ years; maximum 3.6 years, minimum 0.6 years).

The dental loupes used were a SwissLoupe TP-710 (SandyGren$\mathrm{del}^{\oplus}$, Aarburg, Switzerland) with a $2.5 \times$ magnification, a working distance of $350 \mathrm{~mm}$, and an additional LED headlight (SandyGrendel $^{\oplus}$, Aarburg, Switzerland).

Total time for debonding, adhesive removal and polishing was restricted to $45 \mathrm{~min}$. A dental assistant worked together with the operator. The brackets (SPEED System ${ }^{\mathrm{m}}$; Strite Industries, Cambridge, Ontario, Canada) were carefully removed from incisors, cuspids, premolars and molars with sharp debonding pliers (HuFriedy 678-104, Chicago, IL, USA). A tungsten-carbide bur ( $\mathrm{H}$ 379AGK FG; Komet-Brasseler GmbH, Lemgo, Germany) was used for initial adhesive removal at 40,000 revolutions per minute and air cooling. A new bur was used for each patient. An ultrasound instrument and sodium-bicarbonate air-powder abrasive device (AirFlow $^{\oplus}$ S2 with the Piezon ${ }^{\circ}$ scaling instrument type A and the AirFlow ${ }^{\oplus}$ Powder Classic S2; EMS, Nyon, Switzerland) with 70\% power and at a $50 \%$ liquid setting were used to clean the cervical and interproximal enamel. We used silicone polishers (ABBA ${ }^{\circ}$ Universal Polisher pre-polisher black; KerrHawe SA, Bioggio, Switzerland) with water cooling and slurry (Hawe Cleanic with fluoride; KerrHawe SA, Bioggio, Switzerland) with a screw-type cup (hard rubber white 1802/30; KerrHawe SA, Bioggio, Switzerland) to polish.

Dental impressions were taken twice with an A-Silicone (Bisico ${ }^{\circ}$ S1, Bisico ${ }^{\circ}$ S4; Bielefelder Dentalsilicone, Bielefeld, Germany) in a two-step application. Epoxy resin models were made (Stycast ${ }^{\circledR}$ 1266; Emerson and Cuming, Westerlo, Belgium). The tooth replicas were sprayed with gold (SCD 030; Balzers Union, Balzers, Liechtenstein) for $80 \mathrm{~s}$ at $0.08 \mathrm{mbar}$ and $40 \mathrm{~mA}$, resulting in a gold layer of approximately $200 \AA$. Electron microscopic images were taken (TESCAN VEGA TS $5136 \mathrm{XM}$, Cranberry, PA, USA) at a magnification of $50 \times$, and $20 \mathrm{kV}$.

The blinded images were evaluated twice by one examiner at a time interval of 2 weeks. In the case of divergent results from the two assessments, a third evaluation was made using the original epoxy replicas and an optical binocular at a 50× magnification (M7; Wild AG, Heerbrugg, Switzerland). The third evaluation determined the classification. Evaluation included a modified enamel damage index [14] (EDI): 0: smooth surface, perikymata may be visible; 1 : acceptable surface, fine, scattered scratches; 2 : surface with coarse scratches or gouges (Figure 1). Line angle grooves (LAG) were noted including their location on the mesial or distal interproximal side (Figure 2). The presence of any composite residues (CR) was also recorded (Figure 3).

For the statistical analysis, EDI scores 1 and 2 (damage to the enamel surface) were combined and compared to the EDI 0 scores
Form von Oberflächendefekten und „Line-Angle“-Rillen sowie auf Kompositreste hin zu untersuchen.

\section{Material und Methodik}

Nach Zulassung der Studie durch die Ethikkomission der Gesundheitsdirektion Kanton Zürich (StV Nr. 07/05) wurden 22 konsekutive Patienten (13 Frauen, 9 Männer; Alter 16,9 \pm 3 Jahre; Spannweite 14,0-27,6 Jahre) untersucht und 394 Zähne ausgewertet. Zähne, die während der Behandlung neu beklebt werden mussten $(\mathrm{n}=26)$, wurden aus der Studie ausgeschlossen. Ebenfalls ausgeschlossen wurden Zähne mit bukkaler Karies, Demineralisationen oder Füllungen. Es wurde eine Split-Mouth-Studie durchgeführt, bei welcher ein Quadrant pro Kiefer nach dem Zufallsprinzip der Gruppe „Verwendung einer dentalen Lupenbrille“ respektive der Kontrollgruppe zugeteilt wurde. Der kontralaterale Quadrant wurde der jeweils anderen Gruppe zugeteilt. Das Debonding wurde bei allen Patienten von demselben Behandler durchgeführt (mittlere orthodontische Behandlungszeit 2,2 $\pm 0,8$ Jahre; Spannweite 0,6-3,6 Jahre).

Bei der verwendeten Lupenbrille handelte es sich um eine SwissLoupe GT (SandyGrendel ${ }^{\oplus}$, Aarburg, Schweiz) mit einer 2,5-fachen Vergrößerung, einer Arbeitsdistanz von $350 \mathrm{~mm}$ und einem zusätzlichen LED3-Stirnlicht (SandyGrendel ${ }^{\oplus}$, Aarburg, Schweiz).

Die festgelegte maximale Arbeitszeit für Debonding, AdhäsivRestentfernung und Politur betrug 45 Minuten. Der Behandler wurde von einer Dentalassistentin unterstützt. Die Brackets (SPEED System ${ }^{\mathrm{m}}$; Strite Industries, Cambridge, Ontario, Kanada) wurden vorsichtig mittels einer scharfen Debondingzange (HuFriedy 678-104; Chicago, IL, USA) von Inzisiven, Eckzähnen, Prämolaren und Molaren entfernt. Für die initiale Adhäsiv-Restentfernung wurde ein Wolfram-Karbidbohrer (H 379AGK FG; Komet-Brasseler GmbH, Lemgo, Deutschland) bei 40.000 Umdrehungen pro Minute unter Luftkühlung verwendet. Für jeden Patienten wurde ein neuer Bohrer benutzt. Ein Ultraschallinstrument und ein Pulverstrahlgerät (Air-Flow ${ }^{\oplus}$ S2 mit Piezon ${ }^{\star}$ Scaling Instrument Type A und Air-Flow ${ }^{\circ}$ Powder Classic S2; EMS, Nyon, Schweiz) wurden für die Reinigung im zervikalen und approximalen Bereich verwendet. Für die Politur wurden Silikonpolierer (AB$\mathrm{BA}^{\oplus}$ Universal Polisher pre-polisher black; KerrHaweSA, Bioggio, Schweiz) mit Wasserkühlung und Polierpaste (Hawe Cleanic mit Fluoriden; KerrHawe SA, Bioggio, Schweiz) im Näpfchen (hard rubber white 1802/30; KerrHawe SA, Bioggio, Schweiz) benutzt.

Die Abformung der Zähne erfolgte mittels A-Silikon (Bisico ${ }^{\circledR}$ S1, Bisico $^{\circ}$ S4; Bielefelder Dentalsilicone, Bielefeld, Deutschland) in einer zweiphasigen, zweizeitigen Anwendung. Zahnreplika wurden mittels Epoxidharz (Stycast ${ }^{\circledR}$ 1266; Emerson and Cuming, Westerlo, Belgien) hergestellt. Die Modelle wurden 80 Sekunden bei 0,08 mbar und $40 \mathrm{~mA}$ mit Gold beschichtet (SCD 030; Balzers Union, Balzers, Liechtenstein), so wurde eine Schichtdicke von ca. $200 \AA$ erreicht. Die REM-Aufnahmen wurden bei einer 50 -fachen Vergrößerung bei $20 \mathrm{kV}$ aufgenommen (TESCAN VEGA TS $5136 \mathrm{XM}$; Cranberry, PA, USA).

Die REM-Bilder wurden von einem Untersucher im Abstand von zwei Wochen zweimal bewertet. Bei unterschiedlichen Resultaten wurde die Bewertung ein drittes Mal unter Anwendung eines 

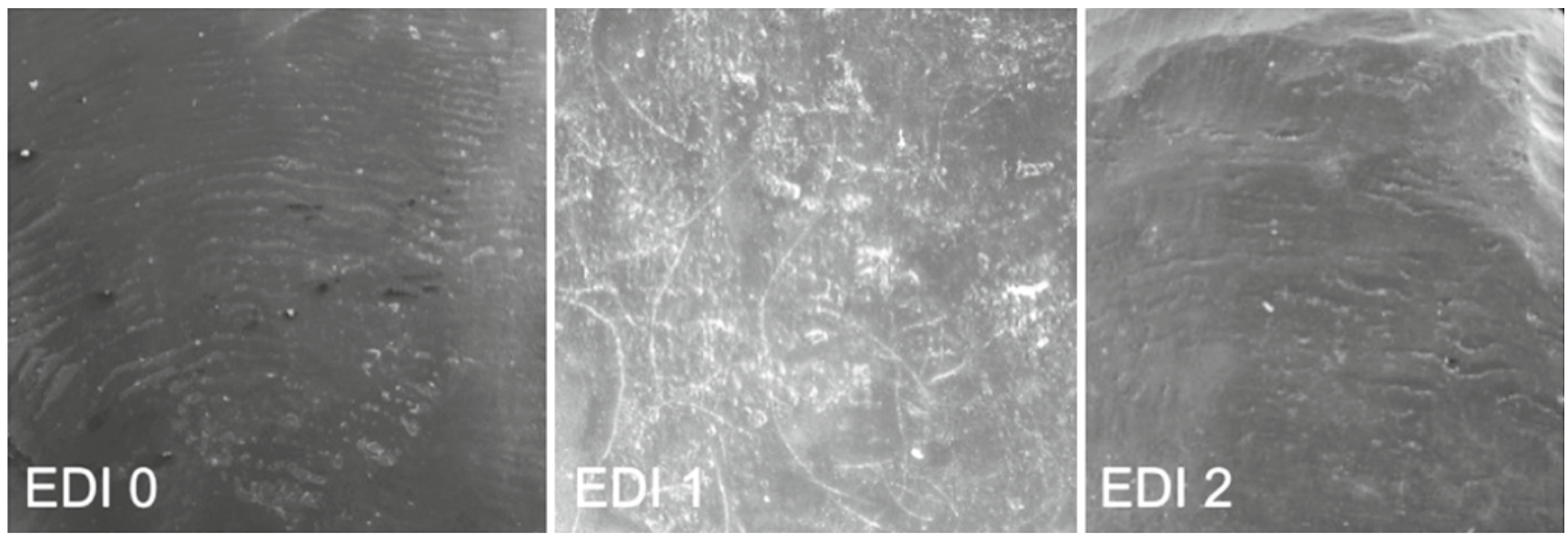

Figure 1. Enamel damage indices (EDI): EDI 0 no damage, EDI 1 scratches, EDI 2 serious damage, at $50 \times$ magnification

Abbildung 1. Schmelzschadenindex: EDI 0 (schadlos), EDI 1 (Kratzer), EDI 2 (größere Schäden) bei 50-facher Vergrößerung

Table 1. Enamel damage index (EDI) on teeth debonded with dental loupes (DL) and without dental loupes (Control). Highly significant differences between the $\mathrm{DL}$ and the control group were found for EDI 0 and EDI $1+2$

Tabelle 1. Schmelz-Schaden-Index (EDI) an Zähnen nach Debonding mit Lupenbrille (DL) und ohne Lupenbrille (Control). Für die EDI-Werte 0 und 1+2 wurden zwischen der Kontroll- und der DL-Gruppe hoch signifikante Unterschiede festgestellt

\begin{tabular}{|c|c|c|}
\hline Debonding method & EDIO & $E D I 1+2$ \\
\hline $\mathrm{DL}(\mathrm{n}=189)$ & 165 & 24 \\
\hline Control $(n=179)$ & $114]^{* * *}$ & $65\rfloor^{* * *}$ \\
\hline
\end{tabular}

(no damage) since only seven teeth in the control group and four in the loupes group had an EDI score of 1 . Due to the paucity of LAG, mesial and distal LAG were also combined. $\chi^{2}$ and Fisher's exact tests were calculated using SPSS ${ }^{\curvearrowleft}$ version 16.0 (SPSS, Chicago, IL, USA). The levels of significance were set at $\mathrm{p} \leq 0.05\left(^{*}\right), 0.01\left(^{* *}\right)$ and $0.001{ }^{(* *)}$.

\section{Results}

Our results are summarized in Table 1-5, illustrating EDI, LAG and CR.

The EDI scores 0,1 and 2 scores $(\mathrm{p}<0.0001)$ differed significantly in their distribution between the dental loupes and control groups (Table 1). We noted no significant differences $(\mathrm{p}=0.08)$ in enamel damage in the control group, but the molars in the dental loupes group revealed significantly more enamel damage $(\mathrm{p}=0.012)$ (Table 2).

LAG revealed similar results when comparing the control to the dental loupes group $(p=0.13)$ (Table 3$)$. We observed significantly fewer LAG in anterior teeth in the dental loupes group than in the control group's anterior teeth $(\mathrm{p}=0.03)$. There were also fewer LAG optischen Binokulars mit 50-facher Vergrößerung (M7; Wild AG, Heerbrugg, Schweiz) durchgeführt. Diese Bewertung war die entscheidende für die definitive Einteilung. Die Auswertung umfasste einen Schmelzschadenindex [14] (EDI): 0: Glatte Oberfläche, Perikymatien zum Teil sichtbar; 1: akzeptable Oberfläche, feine Kratzer; 2: Oberfläche mit groben Kratzern oder Rillen (Abbildung 1). Zudem wurden „Line-Angle“-Rillen inklusive deren mesialer und/ oder distaler Lokalisation (Abbildung 2) sowie Kompositreste notiert (Abbildung 3).

Da nur 7 Zähne in der Kontrollgruppe und 4 in der Lupenbrillengruppe einen EDI von 1 zeigten, wurden für die statistische Analyse die EDI-Werte 1 und 2 (Schmelzoberflächenschäden) kombiniert und mit EDI-Werten 0 (schadlos) verglichen. Aufgrund sehr weniger „Line-Angle“-Rillen wurden die mesialen und distalen „LineAngle“-Rillen ebenfalls kombiniert. Die statistische Auswertung erfolgte über $\chi^{2}$ - und Fisher's-exact-Tests mittels SPSS ${ }^{\circledR}$ (SPSS 16.0, SPSS, Chicago, IL, USA). Die Signifikanzlevel wurden auf $\mathrm{p} \leq 0,05$ $\left({ }^{*}\right), 0,01\left(^{* *}\right)$ und $0,001\left({ }^{* *}\right)$ festgesetzt.

\section{Ergebnisse}

Die Ergebnisse werden in Tabelle 1-5 für Schmelzschäden, „LineAngle"-Rillen und Kompositreste dargestellt.

Die Verteilung der Schmelzschäden war für die EDI-Werte 0 sowie 1 und $2(\mathrm{p}<0,0001)$ signifikant unterschiedlich im Vergleich der Lupenbrillen- mit der Kontrollgruppe (Tabelle 1). Im Hinblick auf die unterschiedlichen Zahngruppen (Tabelle 2) konnten für die Kontrollgruppe keine statistisch signifikanten Unterschiede ( $\mathrm{p}=$ 0,08 ) gefunden werden, allerdings ergaben sich für die Molaren in der Lupenbrillengruppe signifikant mehr Schäden $(p=0,012)$.

Für „Line-Angle“-Rillen wurden ähnliche Werte für Kontrollund Lupenbrillengruppe gefunden $(\mathrm{p}=0,13)$ (Tabelle 3$)$. Auf Frontzähnen der Lupenbrillengruppe traten signifikant seltener „LineAngle“-Rillen auf als auf Frontzähnen der Kontrollgruppe ( $\mathrm{p}=$ 0,03). Zudem traten „Line-Angle“-Rillen auf Frontzähnen der Lupenbrillengruppe signifikant seltener auf als auf Prämolaren ( $\mathrm{p}=$ 0,007) und Molaren $(\mathrm{p}=0,004)$ der Lupenbrillengruppe (Tabelle 4). 


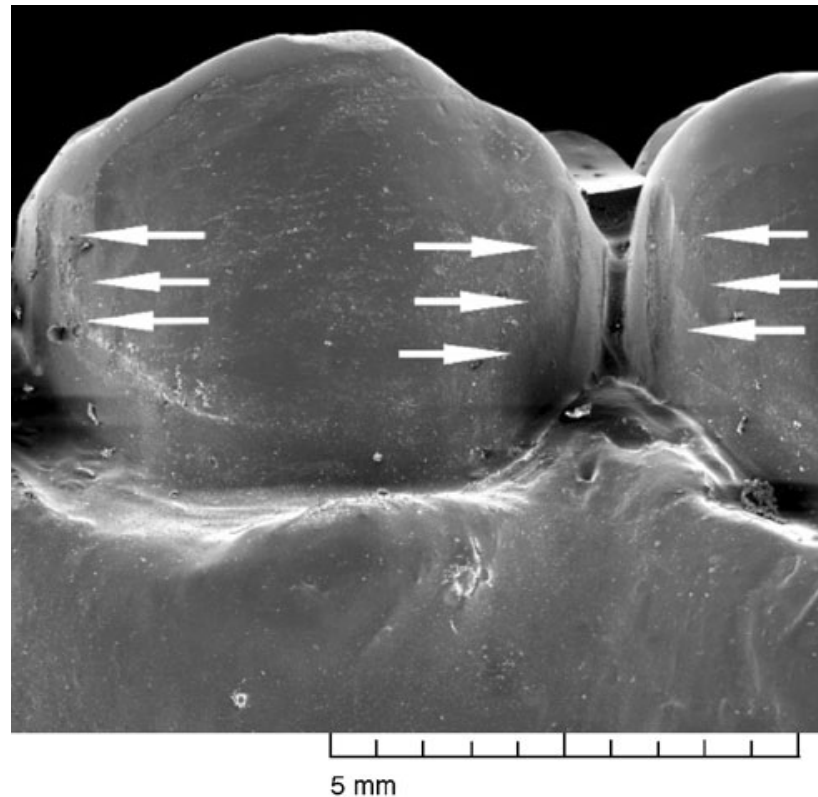

Figure 2. Line angle grooves (LAG) were noted including their location at the mesial or distal interproximal surface

Abbildung 2. "Line-Angle"-Rillen (LAG) wurden zusammen mit deren distaler oder mesialer Lokalisation festgehalten

in premolars $(\mathrm{p}=0.007)$ and molars $(\mathrm{p}=0.004)$ in the dental loupes group than in the control group's respective teeth (Table 4 ).

Composite residues were significantly more frequent $(\mathrm{p}=0.003)$ in the control group (Table 5). The distribution among the teeth did not differ significantly in the control group $(\mathrm{p}=0.13)$ or dental loupes group $(\mathrm{p}=0.74)$.

\section{Discussion}

Enamel can be damaged from the bracket-bonding procedure to adhesive removal. Research has focused on the materials used for adhesive removal since the first study in 1971 [21]. According to many studies cited in our introduction, tungsten-carbide burs are recommended for adhesive removal rather than diamond burs or grinding stones. However, to our knowledge, other aspects potentially affecting adhesive removal-such as differences between orthodontists, or optimizing visual perception by dental loupeshave rarely been investigated. We identified just one study [26] addressing inter-orthodontist differences. Amazingly, but not surprisingly, the same orthodontist scored the best and worst results, indicating that paying close attention could be the most important factor in quality control.

The control group's EDI 1 and 2 scores differed by more than $100 \%$ compared to the EDI scores of the dental loupes group, indicating greater damage to the enamel. As meticulousness might be a major factor in the quality of adhesive removal, we cannot exclude the possibility of an unconscious bias-namely, that an orthodontist may unconsciously take greater care when working with dental loupes. However, a blinded study protocol is not possible.

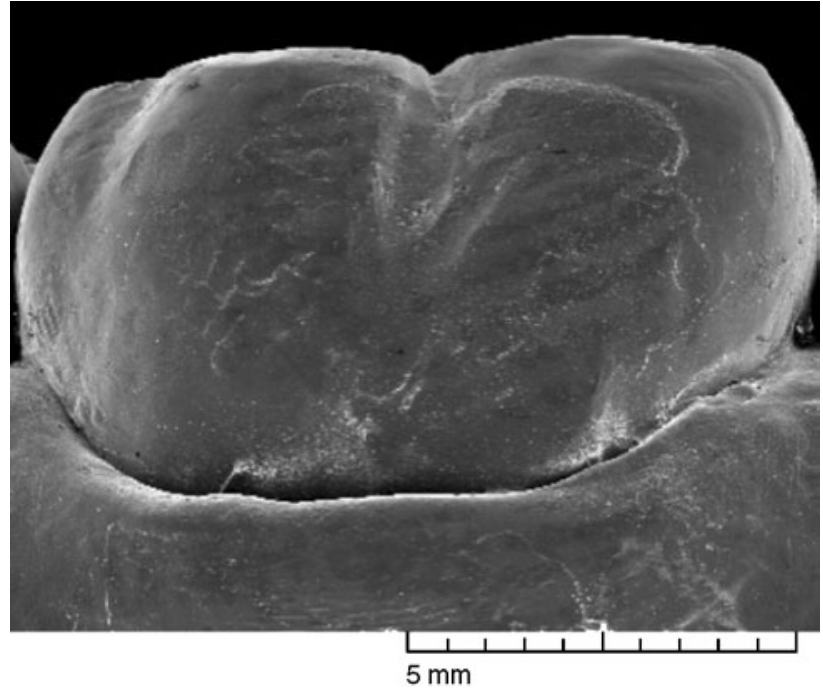

Figure 3. Composite residues (CR) on a lower right molar

Abbildung 3. Kompositreste (CR) an einem unteren rechten Molaren

Kompositreste wurden in der Kontrollgruppe signifikant häufiger $(p=0,003)$ gefunden als in der Lupenbrillengruppe (Tabelle 5). Die Verteilung auf die Zahngruppen war weder für die Kontrollgruppe $(p=0.13)$ noch für die Lupenbrillengruppe $(p=0,74)$ signifikant unterschiedlich.

\section{Diskussion}

Schmelzschäden können über den gesamten Prozess vom Bracketbonding bis zur Adhäsiv-Restentfernung entstehen. Seit der ersten Untersuchung im Jahre 1971 [21] fokussierte dabei die Forschung auf die Materialien, die zur Adhäsiv-Restentfernung verwendet wurden. Gemäß den in der Einleitung zitierten Studien kann geschlossen werden, dass Wolfram-Karbidbohrer für die Adhäsiv-Restentfernung anstelle von Diamantbohrern oder Karborundsteinchen verwendet werden sollten. Hingegen wurden andere Einflussbereiche für die Adhäsiv-Restentfernung, wie Unterschiede zwischen verschiedenen Behandlern oder Verbesserung der visuellen Wahrnehmung durch Lupenbrillen, unseres Wissens kaum untersucht. Es wurde eine Studie [26] zu Unterschieden zwischen verschiedenen Behandlern gefunden. Erstaunlicherweise, aber nicht überraschenderweise, wurden die besten und schlechtesten Resultate bei ein und demselben Behandler festgestellt, was darauf hinweist, dass die Sorgfalt der wichtigste Faktor für die Behandlungsqualität darstellt.

In der Kontrollgruppe unterschieden sich die EDI-Werte um mehr als $100 \%$ von den EDI-Werten der Lupenbrillengruppe, was auf deutlich mehr Schmelzschäden hinweist. Da, wie oben erwähnt, die Sorgfalt einen wesentlichen Einfluss auf die Qualität der Adhäsiv-Restentfernung hat, kann eine unbewusste, unterschiedliche Sorgfalt des Behandlers bei Adhäsiv-Restentfernung mit und ohne Lupenbrille nicht ausgeschlossen werden. Ein Studienprotokoll mit diesbezüglicher Verblindung ist nicht möglich. 
Table 2. Distribution of the enamel damage index (EDI) on different tooth groups for the dental loupes (DL) and the control group: anterior teeth (I incisors, $C$ canines), premolars ( $\mathrm{Pm}$ ) and molars (M). No differences were found in the control group, but significantly more damage was found for molars in the DL group compared to premolars and anterior teeth

Tabelle 2. Verteilung der EDI-Werte auf den unterschiedlichen Zahngruppen nach Debonding mit Lupenbrille (DL) und ohne (Control): Frontzähne (Inzisivi (I) und Eckzähne (C)), Prämolaren (Pm) and Molaren (M). In der Kontrollgruppe wurden keine signifikanten Unterschiede festgestellt. In der DLGruppe fanden sich signifikant mehr Schäden an Molaren

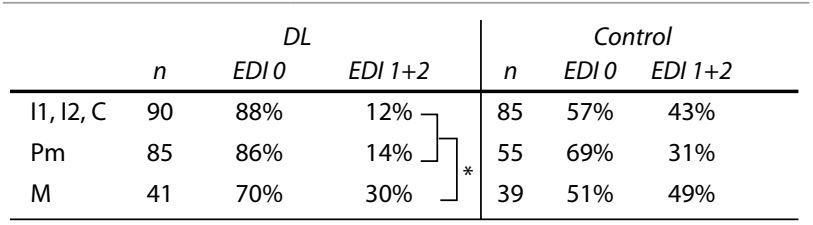

$\left.\mathrm{p} \leq 0.05\left({ }^{*}\right), 0.01{ }^{(* *}\right)$ and $0.001\left(^{* * *}\right)$.

The origin of LAG is not clear. It can be compared to the ripples formed on hard surfaces by milling machines, also known as scoring [6]. LAG may also be due to a prolonged procedure or irregular pressure of the bur at the line angles when the direction of the bur's movement is changed. In contrast to the aforementioned defects reflected in the EDI, we detected no significant difference in the quality of adhesive removal in terms of LAG between the two study groups except for the anterior teeth. The anterior teeth were also those least affected in this study. This may be due to better vision and a tooth morphology facilitating adhesive removal. The broad and relatively straight anterior teeth are probably less prone to LAG. The low frequency of LAG and equal distribution between the control and dental loupes groups reveals that the orthodontist performed extremely careful debonding in both groups. If the main factor for the differences in EDI is the orthodontist's meticulousness, this should also be revealed in how the LAG is distributed. However, incorrect bur positions leading to pronounced LAG might have been visible without magnification, whereas smaller errors leading only to scratches were detected and corrected under magnification. Compared to an earlier investigation [26], our results with loupes were favorable with no cervical grooves and many fewer LAG. According to the preference of the orthodontist the H 379AGK FG tungsten-carbide bur with a slightly tapered shape, rounded tip and eight twisted blades specially developed for orthodontic debonding was used. This bur was proven to be less aggressive in morphological evaluations of teeth after adhesive removal [25]. Its hybrid shapebetween a classical straight finishing bur for buccal adhesive removal and an egg-shaped lingual finishing bur, as well as the rounded, blunt tip-may have effectively inhibited cervical groove formation. The small bracket bases of the bracket system used in this investigation may also have contributed to fewer LAG, as there was probably need to remove adhesive from interproximal areas susceptible to LAG. Ultrasonic and air-powder devices not usually recommended for adhesive removal due to increased chair time [28] were used as a supplementary tool for interdental and cervical cleaning. This may have lessened the tendency to remove staining with the carbide bur rather than composite in those areas, and thus
Table 3. Line angle grooves (LAG) on mesial (mes) and distal (dis) surfaces debonded with dental loupes (DL) and without dental loupes (Control). No significant differences were found

Tabelle 3. "Line-Angle"-Rillen (LAG) an mesialen (mes) und distalen (dis) Zahnflächen nach Debonding mit Lupenbrille (DL) und ohne (Control). Es wurden keine signifikanten Unterschiede gefunden

mes \& dis $L A G$

\begin{tabular}{ll}
\hline $\mathrm{DL}(\mathrm{n}=378)$ & $5 \%$ \\
Control $(n=358)$ & $8 \%$ \\
\hline
\end{tabular}

$\mathrm{p} \leq 0.05\left(^{*}\right), 0.01\left(^{* *}\right)$ and $0.001\left(^{* * *}\right)$.

368 teeth $=736$ mesial $\&$ distal surfaces

Die Ursache der „Line-Angle“-Rillen ist nicht geklärt. „LineAngle“-Rillen könnten mit Riefenbildung auf harten Oberflächen durch Schleifmaschinen verglichen werden, die unter dem Begriff Scoring [6] bekannt sind. Es könnte sich auch um eine verlängerte Einwirkungszeit oder ungleichmäßigen Druck des Bohrers im Umkehrpunkt der Finierbewegung handeln. Im Gegensatz zu den oben genannten Schmelzschäden mittels EDI-Werten konnten, außer für die Frontzähne, zwischen der Kontrollgruppe und der Lupenbrillengruppe keine Unterschiede festgestellt werden. Die Frontzähne waren dabei am wenigsten von „Line-Angle“Rillenbildungen betroffen. Dies könnte auf eine bessere Sicht und eine günstigere Zahnmorphologie der Front für die AdhäsivRestentfernung hindeuten. Die breiten und relativ geraden Zähne sind wahrscheinlich weniger anfällig für das Auftreten von „LineAngle“-Rillen. Der insgesamt geringe Anteil an „Line-Angle“Rillen und die Tatsache, dass eine ähnliche Verteilung in Kontrollund Lupenbrillengruppe vorlag, weist auf ein insgesamt vorsichtiges Vorgehen des Behandlers in beiden Gruppen hin. Wenn die Sorgfalt des Behandlers hauptursächlich für die unterschiedlichen EDIWerte verantwortlich wäre, müsste sich dies auch in der Verteilung der „Line-Angle“-Rillen niederschlagen. Jedoch scheint es gut möglich, dass größere Fehlstellungen des Bohrers, welche in „LineAngle“-Rillen resultieren könnten, ohne optische Vergrößerungshilfe gut gesehen werden, während kleinere Fehler, die zu Verkratzungen der Schmelzoberflächen führen, nur mittels Lupenbrille bemerkt und frühzeitig korrigiert werden. Im Vergleich $\mathrm{zu}$ einer früheren Untersuchung [26] erwiesen sich die Resultate der vorliegenden Studie in Bezug auf Schmelzschäden günstig. Es wurden keine zervikalen Rillen gefunden und „Line-Angle“-Rillen traten deutlich vermindert auf. Gemäß Präferenz des Behandlers wurde der H 379AGK FG Wolfram-Karbidbohrer mit leicht konischer Form, einer gerundeten Spitze und acht verdrillten Schneiden verwendet, welcher speziell für das kieferorthopädische Debonding entwickelt wurde und sich in morphologischen Untersuchungen von Zähnen nach Adhäsiv-Restentfernung als weniger aggressiv dargestellt hatte [25]. Die Form des Finierers, welcher einer Hybridform zwischen klassisch geradem Finierer für Bukkalflächen und eiförmigem Finierer für Lingualflächen entspricht, und die runde, stumpfe Spitze könnten die Bildung von 
Table 4. Distribution of mesial (mes) and distal (dis) line angle grooves (LAG) to the different teeth: anterior teeth (I incisors, $C$ canines), premolars (Pm) and molars (M). Significantly less LAG were found in the dental loupes group (DL) for anterior teeth in comparison to all other groups

Tabelle 4. Verteilung von mesialen (mes) und distalen (dis) „Line-Angle“Rillen (LAG) auf unterschiedlichen Zahngruppen: Frontzähne (Inzisivi (I) und Eckzähne (C)), Prämolaren (Pm) and Molaren (M). Auf den Frontzähnen der Lupenbrillengruppe (DL) wurden im Vergleich zu allen anderen Gruppen signifikant weniger LAG gefunden

\begin{tabular}{|c|c|c|c|c|c|}
\hline & $n$ & $\begin{array}{l}\text { 89) } \\
\text { mes + dis } \\
\quad L A G\end{array}$ & & $n$ & $\begin{array}{c}\text { rol }(n=179) \\
\text { mes }+ \text { dis } \\
L A G\end{array}$ \\
\hline & & & & * & \\
\hline $11,12, C$ & 90 & $2 \%$ & & 85 & $11 \%$ \\
\hline $\mathrm{Pm}$ & 58 & $16 \%$ & $* *$ & 55 & Г $18 \%$ \\
\hline$M$ & 41 & $17 \%$ & & 39 & L $21 \%$ \\
\hline
\end{tabular}

$p \leq 0.05\left(^{*}\right), 0.01\left(^{* *}\right)$ and $0.001\left(^{* *}\right)$.

have contributed to the lack of cervical grooves and lower frequency of LAG. Debonding via air cooling rather than water cooling for better visual control may also have improved the quality of adhesive removal.

We observed only minor differences among the three arch segments. The fact that the anterior segment in EDI, LAG and CR achieved better results, and the lower scores among all the tooth groups in the dental loupes cohort, where consistent with improved quality by enhanced visual control. This concurs with results from an earlier study in which more defects were detected on the posterior than anterior teeth [26].

Careful adhesive removal and efficient methods of restoring the enamel surface as much as possible to its pretreatment state is essential. Our results demonstrate that working with magnification and better illumination results in less severe enamel damage and fewer composite remnants on the enamel surfaces.

\section{Conclusions}

1. Enamel damage on tooth surfaces during adhesive removal was considerably reduced by the wearing of dental loupes.

2. Composite residues were significantly reduced when dental loupes had been worn during adhesive removal.

3. We recommend that dental loupes be worn routinely when removing the adhesive after bracket debonding.

\section{Acknowledgement}

We thank Nils Stucki, Ogar Friedberg, Beatrice Sener and Felix Schmutz for their valuable help and advice, Hans-Ulrich Luder and Margrit Amstad for their assistance with the SEM, and Judith Ball for reviewing the manuscript.

\section{Conflict of interest}

The corresponding author states that there is no conflict of interest.
Table 5. Composite residues (CR) after debonding with dental loupes (DL) and without dental loupes (Control). A significant difference was found for the comparison of the DL and the control group and between most tooth groups

Tabelle 5. Kompositreste (CR) nach Debonding mit Lupenbrille (DL) und ohne Lupenbrille (Control). Es fanden sich signifikante Unterschiede zwischen der DL- und Kontrollgruppe sowie zwischen den meisten Zahngruppen

\begin{tabular}{|c|c|c|c|c|}
\hline \multirow[b]{2}{*}{ total } & \multicolumn{2}{|c|}{$C R D L$} & \multicolumn{2}{|c|}{ CR Control } \\
\hline & $(n=189)$ & $9 \%$ & $(n=179)$ & $21 \%$ \\
\hline $11,12, C$ & $(n=90)$ & $7 \%$ & $\begin{array}{l}* * \\
(\mathrm{n}=85)\end{array}$ & $\boldsymbol{H}^{19 \%}$ \\
\hline $\mathrm{Pm}$ & $(n=58)$ & $10 \%$ & $\stackrel{*}{(n=55)}$ & $15 \%$ \\
\hline$M$ & $(n=41)$ & $10 \%$ & $\begin{array}{l}(n=39) \\
* *\end{array}$ & $36 \%$ \\
\hline
\end{tabular}

zervikalen Rillen vermeiden geholfen haben. Zudem könnten die schmalen Bracketbasen dazu beigetragen haben, dass weniger „Line-Angle“-Rillen entstanden, da weniger Adhäsiv im approximalen Bereich entfernt werden musste. Die Verwendung von Ultraschall und Pulverstrahlgeräten, welche aufgrund der geringeren Effizienz üblicherweise nicht für die AdhäsivRestentfernung empfohlen werden [28], wurden begleitend für die Reinigung der interdentalen und zervikalen Bereiche eingesetzt. Dies könnte die Tendenz, Verfärbungen in diesen Bereichen mit dem Finierer zu entfernen, vermindert und dadurch das Auftreten von LAG und zervikalen Rillen reduziert haben. Auch die AdhäsivRestentfernung unter Luftkühlung anstelle von Wasserkühlung, welche mit einer besseren visuellen Kontrolle einhergeht, könnte zu den besseren Resultaten beigetragen haben.

Innerhalb der drei untersuchten Zahnsegmente konnten nur kleine Unterschiede festgestellt werden. Die besseren Resultate für das Frontsegment bezüglich Schmelzschäden, „Line-Angle“-Rillen und Kompositresten und die reduzierten Werte für alle Zähne in der Lupenbrillengruppe bestätigen den Einfluss begünstigter Sichtverhältnisse auf die Qualität der Adhäsiv-Restentfernung. Dies steht in Übereinstimmung mit einer früheren Studie, bei der in posterioren Bereichen mehr Defekte als in anterioren Bereichen gefunden wurden [26].

Sorgfältige Adhäsiv-Restentfernung und effiziente Methoden zur Wiederherstellung einer möglichst idealen Schmelzoberfläche sollten in der kieferorthopädischen Behandlung Standard sein. Die Resultate zeigten, dass die Arbeit mit Lupenbrille und verbesserter Beleuchtung zu weniger Schmelzschäden und weniger Kompositresten auf Schmelzoberflächen führte.

\section{Schlussfolgerungen}

1. Schmelzschäden auf Zahnoberflächen während der AdhäsivRestentfernung wurden durch die Verwendung von Lupenbrillen deutlich reduziert. 


\section{References}

1. Al Shamsi AH, Cunningham JL, Laamey PJ, Lynch E (2007) Three-dimensional measurement of residual adhesive and enamel loss on teeth after debonding of orthodontic brackets: An in-vitro study. Am J Orthod Dentofacial Orthop 131:301.e9-301.e15

2. Brown CR, Way DC (1978) Enamel loss during orthodontic bonding and subsequent loss during removal of filled and unfilled adhesives. Am J Orthod 74:663671

3. Caspersen I (1977) Residual acrylic adhesive after removal of plastic orthodontic brackets: a scanning electron microscopic study. Am J Orthod 71:637-650

4. Christensen GJ (2003) Magnification in dentistry: useful tool or another gimmick? J Am Dent Assoc 134:1647-1650

5. Diedrich P (1981) Enamel alterations from bracket bonding and debonding: a study with the scanning electron microscope. Am J Orthod 79:500-522

6. DIN Standard 6580 ( $n$ d) Terminology of chip removing; movements and geometry of the chip removing process: DIN Group, German Institute for Standardization, Berlin, Germany

7. Eliades T, Gioka C, Eliades G, Makou M (2004) Enamel surface roughness following debonding using two resin grinding methods. Eur J Orthod 26:333-338

8. Forgie AH, Pine CM, Pitts NB (2001) Restoration removal with and without the aid of magnification. J Oral Rehabil 28:309-313

9. Friedman MJ, Mora AF, Schmidt R (1999) Microscope-assisted precision dentistry. Compend Contin Educ Dent 20:723-728, 730-731, 735-736, quiz737

10. Friedman MJ (2004) Magnification in a restorative dental practice: from loupes to microscopes. Compend Contin Educ Dent 25:48, 50, 53-55

11. Hannemann M, Diedrich P (1986) Der Einsatz des Prophy-Jet ${ }^{\oplus}$-Gerätes zur Schmelzpolitur nach der Bracketentfernung. Fortschr Kieferorthop 47:317-326

12. Hong YH, Lew KK (1995) Quantitative and qualitative assessment of enamel surface following five composite removal methods after bracket debonding. Eur J Orthod 17:121-128

13. Hosein I, Sherriff M, Ireland AJ (2004) Enamel loss during bonding, debonding, and cleanup with use of a self-etching primer. Am J Orthod Dentofacial Orthop 126:717-724

14. Howell S, Weekes WT (1990) An electron microscopic evaluation of the ename surface subsequent to various debonding procedures. Aust Dent J 35:245-252

15. Kim SS, ParkWK, Son WS et al (2007) Enamel surface evaluation after removal of orthodontic composite remnants by intraoral sandblasting: a 3-dimensional surface profilometry study. Am J Orthod Dentofacial Orthop 132:71-76

16. Krell KV, Courey JM, Bishara SE (1993) Orthodontic bracket removal using conventional and ultrasonic debonding techniques, enamel loss, and time requirements. Am J Orthod Dentofacial Orthop 103:258-266

17. Lussi A, Kronenberg O, Megert B (2003) The effect of magnification on the iatrogenic damage to adjacent tooth surfaces during class II preparation. J Dent 31:291-296

18. Maillet JP, Millar AM, Burke JM et al (2008) Effect of magnification loupes on dental hygiene student posture. J Dent Educ 72:33-44

19. Mannerberg F (1968) Appearance of tooth surface of teeth showing dental fluorosis as observed by shadowed replicas. Odontol Revy 19:271-291

20. Millar BJ (1998) Focus on loupes. Br Dent J 185:504-508

21. Newman GV, Facq JM (1971) The effects of adhesive systems on tooth surfaces. Am J Orthod 59:67-76

22. Øgaard B (2001) Oral microbiological changes, long term enamel alterations due to decalcification and caries prophylactic aspects. In: Brantley WA, Eliades T (eds) Orthodontic materials: scientific and clinical aspects. Thieme, Stuttgart, S 124-39

23. Oliver RG, Griffiths J (1992) Different techniques of residual composite removal following debonding - time taken and surface enamel appearance. $\mathrm{Br} J$ Orthod 19:131-137

24. Özer T, Başaran G, Kama JD (2010) Surface roughness of the restored enamel after orthodontic treatment. Am J Orthod Dentofacial Orthop 137:368-374

25. Radlanski RJ (2001) A new carbide finishing bur for bracket debonding. J Orofac Orthop 62:296-304
2. Kompositreste wurden durch die Verwendung einer Lupenbrille deutlich reduziert.

3. Dentale Lupenbrillen werden für den routinemäßigen Einsatz bei Adhäsiv-Restentfernung empfohlen.

\section{Danksagung}

Wir bedanken uns bei Nils Stucki, Ogar Friedberg, Beatrice Sener und Felix Schmutz für ihre Unterstützung, Hans-Ulrich Luder und Margrit Amstad für die Hilfe bei den REM-Aufnahmen und Judith Ball für das Korrekturlesen.

\section{Interessenkonflikt}

Der korrespondierende Autor gibt an, dass kein Interessenkonflikt besteht.

26. Schuler FS, Van Waes H (2003) SEM-evaluation of enamel surfaces after removal of fixed orthodontic appliances. Am J Dent 16:390-394

27. Sims AP, Roberts-Harry TJ, Roberts-Harry DP (1993) The incidence and prevention of ocular injuries in orthodontic practice. Br J Orthod 20:339-343

28. Staribratova-Reister K, Jost-Brinkmann PG (2004) Bonding and debonding characteristics of APC-plus clarity brackets compared to APC clarity brackets. World J Orthod 5:312-316

29. Strobl K, Bahns TL, Willham L et al (1992) Laser-aided debonding of orthodontic ceramic brackets. Am J Orthod Dentofacial Orthop 101:152-158

30. Thompson RE, Way DC (1981) Enamel loss due to prophylaxis and multiple bonding/debonding of orthodontic attachments. Am J Orthod 79:282-295

31. Van Waes H, Matter T, Krejci I (1997) Three-dimensional measurement of enamel loss caused by bonding and debonding of orthodontic brackets. Am J Orthod Dentofacial Orthop 112:666-669

32. Zachrisson BU, Arthun J (1979) Enamel surface appearance after various debonding techniques. Am J Orthod 75:121-127

33. Zarrinnia K, Eid NM, Kehoe MJ (1995) The effect of different debonding techniques on the enamel surface: an in vitro qualitative study. Am J Orthod Dentofacial Orthop 108:284-293

\section{Correspondence address}

Dr. Dr. Lorenz Brauchli

Department of Orthodontics and Pedodontics

University of Basel

Hebelstrasse 3

4056 Basel

Switzerland

Phone: (+41/61) 267 26-46, Fax: -57

e-mail:Lorenz.Brauchli@unibas.ch 